\title{
PENGELOLAAN LIMBAH KAWASAN INDUSTRI KECIL DI KOTA TEGAL
}

\author{
Oleh : \\ Setiyono dan Heru Dwi Wahjono \\ Peneliti di Pusat Teknologi Lingkungan, BPPT
}

\begin{abstract}
Tegal is a maritime town that mostly its resident has living as fisherman. Most existing industry in this town is fishery industry. Besides fishery industry, other small industrial also produce waste water which together with domestic waste water partake to contaminate Gung river, Sibelis river, Kemiri river and other channel which pass through Tegal town. Tegal town government trough the Office Operation of Environmental Impact (KEPADEL) have conducted various effort to reduce the impact of environmental contamination by giving counseling, training and other compilation of book containing information technology and technical guidance of waste water management to industrial activity exist in Tegal. With construction which continues to be conducted by KAPEDAL, we expected that the environmental quality in this town will change with progressively goodness.
\end{abstract}

Kata Kunci : Kawasan Industri, Limbah Cair Industri, Pencemaran Lingkungan, Informasi Teknologi Pengelolaan Limbah.

\section{PENDAHULUAN}

Berbagai upaya telah dilakukan oleh pemerintah daerah Kota Tegal untuk mengurangi terjadinya pencemaran lingkungan sebagai akibat adanya kegiatan industri, antara lain dengan pengembangan proses produksi bersih (nir limbah), minimisasi limbah, penggantian bahan berbahaya dengan bahan yang lebih aman maupun dengan teknologi pengolahan limbah (end of pipe). Meskipun berbagai cara telah ditempuh untuk mencapai proses produksi bersih, tetapi teknologi yang ada belum dapat diterapkan pada semua sektor industri yang ada. Jika langkah-langkah minimisasi limbah telah ditempuh tetapi limbah masih dihasilkan, maka langkah pengolahan harus dilakukan. Teknologi pengolahan limbah meskipun digunakan sebagai pilihan penyelesaian terakhir dan dianggap kurang effisien, tetapi sampai saat ini teknologi ini masih sangat diperlukan.

Berbagai ketentuan dan peraturan perundangan juga telah diterbitkan untuk mencegah, mengurangi dan mengendalikan kerusakan lingkungan akibat berbagai kegiatan, namun jika semua itu tanpa diikuti oleh kesadaran dari semua pihak untuk mendukung program-program pelestarian lingkungan, mustahil akan dapat berjalan. Perlu juga disadari, bahwa program pelestarian memerlukan biaya yang cukup, namun ini merupakan program investasi jangka panjang yang harus disadari bersama. Salah satu program ini adalah adanya kewajiban untuk mengelola dan mengolah limbah yang dihasilkan oleh setiap kegiatan/aktivitas manusia.
Pada umumnya industri kecil atau rumah tangga sampai saat ini masih memiliki kendala dalam melakukan pengolahan limbahnya. Agar para pengusaha kecil dapat mengolah limbahnya maka perlu diberikan teknologi pengolahan limbah yang sederhana, effisien, dan effective agar tidak banyak membebani biaya operasional perusahaan.

Dari hasil survai yang dilakukan Kapedal Kota Tegal tahun 2005 diketahui bahwa :

- Sebagian besar industri filet di kota Tegal merupakan industri kecil dan rumah tangga.

- Sebagian pengusaha filet ikan pernah melakukan upaya pengelolaan lingkungan dan pengolahan limbah.

- Banyak fasilitas pengolahan limbah yang telah dibangun tidak dapat beroperasi dengan baik.

- Industri yang ada belum mengetahui informasi teknologi yang tepat untuk menangani pemasalahan limbahnya.

\section{TUJUAN DAN SASARAN}

Kegiatan ini bertujuan memberikan panduan pengelolaan limbah, memberikan panduan pemilihan teknologi IPAL yang efective dan efisien, dan memberikan teknologi sederhana untuk membantu pengusaha kecil agar dapat mengolah limbahnya dengan biaya yang murah. Sedangkan sasarannya adalah melakukan identifikasi dan evaluasi terhadap permasalahan lingkungan di wilayah kota Tegal, serta membuat dokumen panduan teknis sistem pengolahan lingkungan industri. 


\section{METODOLOGI}

Metodologi pelaksanaan kegiatan ini adalah sebagai berikut:

- Survai lapangan yang dilaksanakan di wilayah Kota Tegal dengan melakukan observasi lapangan dan perencanaan penentuan pengambilan data-data sekunder. Selain itu juga dilakukan perencanaan disain teknis sistem pengolahan air limbah.

- Pengumpulan data, dengan target mendapatkan data-data sebagai berikut:

a.Peta wilayah Kota Tegal.

b. Data jumlah dan sebaran lokasi industri.

c. Data presepsi masyarakat terhadap pengolahan limbah saat ini serta kendalakendala yang muncul.

- Pengolahan data dan analisis, yaitu dengan melakukan pengolahan data sekunder dan data primer dengan bantuan perangkat lunak basis data dan statistik kemudian hasilnya dianalisa dan dibahas.

\section{HASIL YANG DIHARAPKAN}

Hasil yang diharapkan dari pekerjaan ini adalah sebagai berikut :

1) Diperolehnya data tentang sebaran industri dan kondisi lingkungannya dan permasalahan lingkungan yang ada.

2) Diperolehnya gambaran tentang rencana pengelolaan lingkungan industri.

3) Hasil evaluasi dari kegiatan program ini yang mencakup informasi tentang kondisi lingkungan industri untuk dapat digunakan sebagai pendukung pengambilan keputusan dalam menentukan kebijakan pengelelolaan lingkungan industri di Kota Tegal.

\section{HASIL DAN PEMBAHASAN}

\subsection{Kriteria Industri dan Usaha Dagang Kecil}

Berdasarkan Kepmen. Perindustrian dan Perdagangan RI Nomor 254/MPP/Kep/7/1997, tentang "Kriteria Industri Kecil di Lingkungan Departemen Perindustrian dan Perdagangan Republik Indonesia", yang dimaksud dengan Industri Kecil dan Perdagangan Kecil di lingkungan Departemen Perindustrian dan Perdagangan sebagai berikut :

a. nilai investasi perusahaan seluruhnya sampai dengan Rp. 200.000.000 (dua ratus juta rupiah) tidak termasuk tanah dan bangunan tempat usaha;

b. pemilik Warga Negara Indonesia;

\subsection{Peran Industri Kecil Dalam Pembangun- an Ekonomi}

Industri kecil di Indonesia sungguh berperan penting dalam pembangunan ekonomi nasional. Justru dari golongan industri kecil ini yang lebih tampak nyata mempunyai ketahanan yang jauh lebih baik dari pada sejumlah industri besar. Hal tersebut sudah terbukti sejak terjadinya krisis moneter tahun 1997 yang melanda Indonesia hingga sekarang ini.

Dalam masa krisis tersebut, ditambah lagi dengan krisis bahan bakar minyak pada bulan September 2005 ternyata sebagian industri raksasa satu demi satu gulung tikar menutup operasinya. Hanya sedikit saja industri kecil yang mati, itupun karena sedikitnya keuntungan yang diperoleh dan besarnya tuntutan biaya operasional yang semakin besar. Dengan tingkat suku bunga yang oleh Bank ditekan berkisar $11,5 \%$ untuk keredit usaha kecil, justru ada banyak usaha kecil yang muncul dan tumbuh dengan prospek yang menggembirakan.

Di kota Tegal ada beberapa jenis usaha industri kecil yang dikembangkan oleh mayarakat Kota Tegal. Jenis-jenis industri kecil yang ada di Kota Tegal antara lain : industri tahu dan tempe, industri saos, industri kecap, percetakan umum, batik, filet ikan, tepung ikan, tepung beras, shutle kok dan lain-lain. Dari berbagai industri tersebut sebagain besar masih menghadapi kendala dalam melakukan pengelolaan limbahnya, yaitu:

- minimnya pengetahuan tentang lingkungan,

- masih kurangnya kesadaran untuk menjaga lingkungan,

- kurangnya modal usaha dan biaya untuk pelestarian lingkungan,

- kurangnya informasi tentang teknologi lingkungan yang murah dan effisien.

\subsection{Kondisi Lingkungan Industri Filet Ikan}

Kapedal Kota Tegal telah mengadakan survai pemantauan secara langsung kondisi lingkungan industri filet ikan yang ada. Dari hasil survai ini diharapkan dapat memberikan masukan kepada semua pihak yang berkepentingan dengan perkembangan industri dan pembinaan lingkungan industri di Kota Tegal. Dalam survai ini juga dipelajari tentang pemahaman masyarakat industri tentang upaya pelestarian lingkungan.

Dari hasil survai dapat disimpulkan kondisi lingkungan industri filet ikan di kota Tegal, yaitu:

- Pada umumnya merupakan industri kecil dan rumah tangga.

- Sebagian besar SDM yang ada merupakan tenaga terampil yang mendapatkan keahlian dari pengalaman kerja di perusahaan. 
- Sebagian besar industri menggunakan teknik produksi atau peralatan tradisional.

- Ada beberapa industri filet yang berkembang dengan teknologi maju.

- Beberapa pengusaha pernah melakukan upaya pengelolaan lingkungannya.

- Semua fasilitas pengolahan limbah industri filet yang ada tidak dapat beroperasi.

Gambar 1 dan gambar 2 di bawah ini memperlihatkan aktifitas kegiatan industri dan pengelolaan limbah cair dan padat di industri filet ikan yang ada di Kota Tegal.

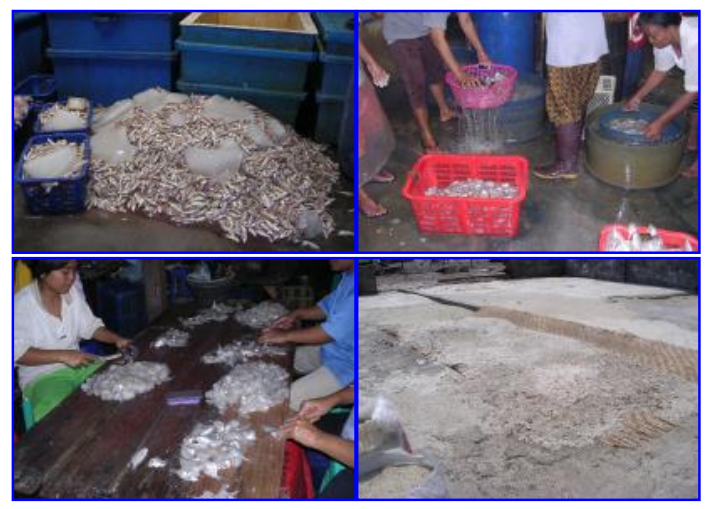

Gambar 1: Kegiatan Produksi Filet Ikan.

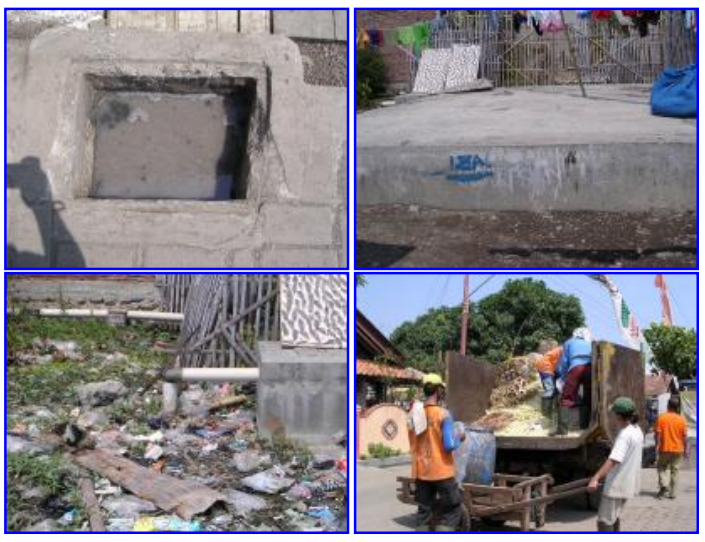

Gambar 2 : Pengelolaan Limbah Cair Dan Padat Industri Filet Ikan.

Sebagian besar para pengusaha filet di kota Tegal memiliki keinginan untuk melakukan pengelolaan lingkungan dan mengolah limbahnya. Hal ini ditunjukkan dengan telah dibangunnya fasilitas pengolahan limbah di beberapa industri, tetapi semua IPAL yang ada tidak dapat beroperasi sesuai yang diharapkan. Gambar 3. adalah salah satu contoh fasilitas IPAL yang telah dibangun namun tidak dioperasikan oleh industri filet ikan.

Masih banyak kendala yang menyebabkan tidak beroperasinya sarana IPAL tersebut, diantaranya adalah:

- SDM yang ada kurang memahami sistem manajemen lingkungan yang berkelanjutan.
- Rendahnya penguasaan teknologi IPAL.

- Penerapan teknologi IPAL banyak yang kurang tepat.

- IPAL yang telah dibangun tidak didukung dengan fasilitas pengelolaan air limbah yang baik.

- Sebagian industri yang ada merupakan industri kecil yang bermodal rendah, sehingga faktor pembiayaan sering menjadi kendala.

- Tidak adanya fasilitas kawasan industri yang dapat dimanfaatkan oleh para pengusaha.

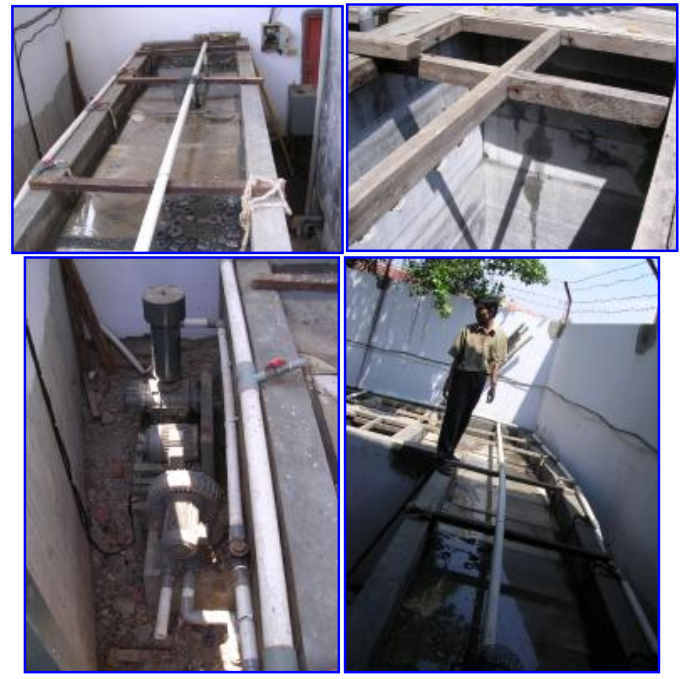

Gambar 3 : IPAL Industri Filet Ikan di Kota Tegal.

Dengan adanya berbagai kendala tersebut, kiranya peran KAPEDAL Kota Tegal untuk membina para pengusaha/industri lebih diharapkan. Dengan adanya pembinanaanyang dilakukan tentang pengelolaan lingkungan dan peningkatan kemampuan SDM dalam melakukan upaya pengendalian pencemaran lingkungan dengan menguasai teknologi pengolahan limbah diharapkan dapat meningkatkan kualitas lingkungan yang ada.

\subsection{Sumber Limbah}

Ada beberapa sumber limbah dari industri filet, yaitu :

- dari proses produksi,

- sisa produk (serpihan ikan),

- ikan yang rusak,

- ceceran produk di lingkungan kerja,

- air cucian,

- dari kamar mandi dan toilet,

- dari wastafle,

- dari kantin,

- dari air untuk membersihkan lingkungan. 


\subsection{Faktor Yang Mempengaruhi Timbulnya Limbah}

Setiap kegiatan menghasilkan limbah dengan jumlah dan karakteristik yang berlainan. Meskipun jenis dan besaran kegiatan suatu industri sama, belum tentu jumlah dan karakteristik limbahnya sama. Jika dianalisa lebih detail, jumlah dan karakteristik limbah banyak dipengaruhi oleh berbagai faktor-faktor sebagai berikut:

- Peralatan proses yang tidak bekerja pada kondisi optimum,

- Peralatan /fasilitas kerja yang kurang memenuhi persyaratan/ minim,

- Ketrampilan kerja dan kemampuan kerja dari SDM,

- Tingkat kesadaran SDM untuk menjaga lingkungan kerja,

- Hubungan kerja antar unit yang ada,

- SOP yang ada.

Dengan mengetahui sumber limbah dan faktor-faktor yang mempengaruhinya, diharapkan dapat dimonitor dan ditekan seminimal mungkin limbah yang ada. Dengan meminimalisasikan limbah dan mengelola limbah sesuai dengan prosedur pengelolaan yang benar kita mendapatkan berbagai keuntungan, yakni :

- mengurangi kehilangan bahan baku/ produk,

- meningkatkan effisiensi proses produksi dan kerja,

- menghemat biaya pengolahan limbah,

- mengurangi resiko kecelakaan kerja,

- mengurangi resiko bencana akibat pencemaran limbah,

- menghindarkan konflik sosial dengan lingkungan sekitar akibat limbah,

- meningkatkan emage di mata konsumen, karena kita telah melakukan proses produksi bersih.

- meningkatkan jumlah penjualan produk dll.

\subsection{Strategi Pengelolaan Limbah Industri Kecil / Rumah Tangga}

Industri kecil atau industri rumah tangga secara umum keberadaannya adalah menyebar, namun ada juga yang terkonsentrasi dalam satu sentra industri kecil. Pada umumnya industri seperti ini mempunyai ciri-ciri sebagai berikut :

- berkembang dengan modal usaha kecil,

- menggunakan teknik produksi dan peralatan yang sederhana,

- keselamatan dan kesehatan kerja kurang mendapatkan perhatian,

- tingkat pendidikan SDM nya relatif rendah,

- kegiatan riset dan pengembangan usaha masih minim,
- belum mengutamakan faktor kelestarian lingkungan,

- belum mampu mengolah limbahnya sampai memenuhi baku mutu yang berlaku.

Dengan kondisi seperti ini, maka perlu disediakan teknologi yang sederhana yang dapat diterapkan oleh para pengusaha tanpa merasa terbebani sehingga pengolahan limbah dapat diterapkan dan dioperasikan dengan benar.

Untuk menghindari terjadinya pencemaran akibat timbulnya limbah industri, maka diperlukan pengelolaan limbah dengan benar dan tentunya dengan biaya yang seminimal mungkin. Hal ini harus dilakukan mulai dari sumbernya dan proses produksi yang ada, yaitu dengan penerapan teknologi bersih (nir-limbah), minimalisasi limbah (re-use, recycle dan lainlain), baru teknologi pengolahan limbah sebagai alternatif terakhir.

\subsection{Teknologi Produksi Bersih}

Teknologi produksi bersih merupakan suatu konsep yang dikembangkan sebagai tindak lanjut dari Konferensi Dunia tentang Lingkungan dan Pembangunan (World Summit on Sustainable Development) yang diselenggarakan di Rio de Janerio pada tahun 1992. Teknologi produksi bersih terkait erat dengan program Agenda 21 dan merupakan salah satu jalan menuju pembangunan ekonomi yang berkelanjutan dan pemanfaatan ilmu pengetahuan dan teknologi ramah lingkungan (Raka, Zen, Soemarwoto, Djajadiningrat, siadi, 1999).

Program produksi bersih merupakan upaya proaktif dalam sistem produksi untuk tidak melakukan tindakan dan proses apapun sebelum yakin benar bahwa produknya nanti akan lebih ramah terhadap lingkungan. Pengalaman juga menunjukkan bahwa dengan menerapkan produksi bersih pada industri biaya produksi dapat dipotong secara nyata, disamping itu dapat mengamankan kelestarian peran dan fungsi lingkungan.

\subsection{Minimisasi Limbah}

Adanya pengolahan limbah merupakan suatu tambahan proses pada industri, sedangkan minimisasi limbah melibatkan semua aspek pada proses produksi yang rumit. Adanya pendapat bahwa pengontrolan polusi dan minimisasi limbah merupakan tujuan jangka panjang, tidak dapat dicapai dan tidak sesuai untuk strategi jangka pendek telah mendesak para penghasil limbah untuk mencari berbagai alternatif dalam upaya minimisasi limbah, namun yang menjadi penghambat upaya tersebut adalah resiko 
terjadinya perubahan kualitas produk akibat pengerjaan minimisasi limbah yang dikerjakan dengan merubah proses industri yang sematamata hanya untuk menurunkan jumlah limbah yang dihasilkan tanpa didasari oleh keahlian khusus.

Semestinya upaya untuk menurunkan jumlah limbah haruslah dapat mendatangkan keuntungan terhadap lingkungan melalui pencegahan polusi dan penghematan biaya industri sehingga akan mendatangkan perbaikan ekonomi. Usaha minimisasi limbah yang berhasil biasanya merupakan hasil dari peningkatan effisiensi operasional industri tersebut, yang mana sebagian upaya tersebut akan menghasilkan produk samping, tidak hanya difokuskan pada pengubahan proses industri.

Ada beberapa pendekatan teknik minimisasi limbah yang tepat untuk mengurangi jumlah limbah antara lain :

- recycling limbah atau sebagian dari limbah,

- memperbaiki terminologi proses dan peralatan yang akan mengubah sumber limbah utama,

- memperbaiki operasi pabrik seperti melakukan house keeping yang terbaik, memperbaiki cara pengangkutan material dan merawat peralatan, outomatisasi peralatan proses, monitoring dan meningkatkan pengelolaan limbah, memadukan penghitungan neraca bahan ke dalam proses desain.

- Subtitusi bahan baku yang menyebabkan dihasilkannya bahan berbahaya,

- Redisain atau reformulasi produk akhir.

Banyak industri yang ingin mengurangi jumlah limbahnya, tetapi tidak mengetahui bagaimana memulainya dan menerapkan ke dalam permasalahan yang komplek. Untuk mencapai sasaran tersebut perlu dilakukan prioritas dalam pelaksanaannya. Gambar 4 merupakan urutan prioritas untuk meminimalisasi limbah berbahaya yang dihasilkan. Pada kondisi ideal penghilangan limbah berbahaya secara total adalah merupakan sesuatu yang memungkinkan.

\subsection{Teknologi Pengolahan Limbah}

Pengolahan air limbah bertujuan untuk menghilangkan parameter pencemar yang ada di dalam air limbah sampai batas yang diperbolehkan untuk dibuang ke badan air sesuai dengan syarat baku mutu yang diijinkan. Pengolahan air limbah secara garis besar dapat dibagi yakni pemisahan padatan tersuspensi (solid-liquid separation), pemisahan senyawa koloid, serta penghilangan senyawa polutan terlarut. Ditinjau dari jenis prosesnya dapat dikelompokkan : proses pengolahan secara fisika, proses secara kimia, proses secara fisikakimia serta proses pengolahan secara biologis.

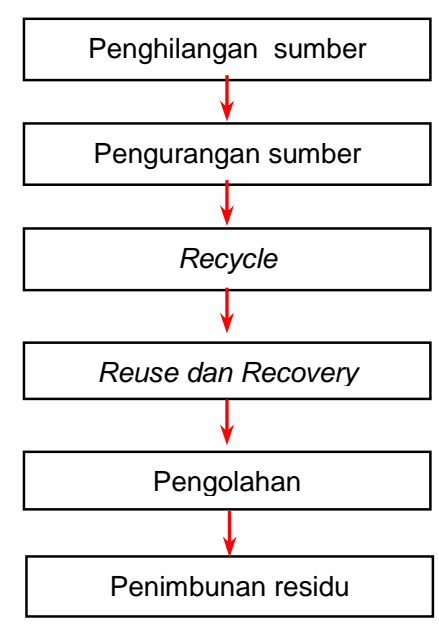

Gambar 4. Urutan Prioritas Untuk Meminimalisasi Limbah.

Ditinjau dari urutannya proses pengolahan air limbah dapat dibagi menjadi tiga jenis pengolahan, yakni :

- Pengolahan Primer, digunakan sebagai pengolahan pendahuluan untuk menghilangkan padatan tersuspensi, koloid, serta penetralan yang umumnya menggunakan proses fisika atau proses kimia.

- Pengolahan Sekunder, digunakan untuk menghilangkan senyawa polutan organik terlarut yang umumnya dilakukan secara proses biologis.

- Pengolahan Tersier atau Pengolahan Lanjut, digunakan untuk menghasilkan air olahan dengan kualitas yang lebih bagus sesuai dengan yang diharapkan. Prosesnya dapat dilakukan baik secara biologis, secara fisika, kimia atau kombinasi ke tiga proses tersebut.

Ada beberapa faktor yang harus dipertimbangkan dan dipenuhui sebelum menentukan proses pengolahan dan sistem yang akan digunakan. Jika terjadi kesalahan dalam pemilihan teknologi ini, maka IPAL yang dibangun tidak akan memberikan hasil olahan yang optimal.

\subsection{Perencanaan IPAL}

Pemilihan proses dan sistem yang tidak tepat atau disain IPAL yang salah akan menimbulkan berbagai persoalan di dalam IPAL itu sendiri, misalnya :

- biaya investasi, operasional maupun perawatannya akan menjadi mahal,

- sistem tidak dapat bekerja secara optimal,

- hasil olahan tidak seperti yang diinginkan,

- sulit dalam pengendalian/operasional. 
Untuk menghindari hal-hal seperti tersebut di atas, maka dalam perencanaan suatu IPAL harus dilakukan tahap demi tahap secara berurutan dimulai dari upaya minimisasi limbah, manajemen pengelolaan limbah, sampai dengan pemilihan teknologi dan sistem.

Dalam satu jenis limbah dengan karakteristik tertentu terkadang mengandung berbagai macam bahan pencemar di dalamnya, yang mana setiap jenis polutan tersebut mempunyai sifat-sifat yang berlainan. Jika menghadapi limbah seperti ini, maka diperlukan teknik-teknik untuk mengkombinasikan proses maupun sistem yang akan digunakan, yang mana sistem manajemen limbah dari sumbernya juga memegang peran yang sangat penting.

Gambar 5 pada lampiran menunjukkan contoh diagram alir sistem pengelolaan limbah dari sumbernya. Sedangkan Gambar 6 dan 7 pada lampiran menunjukkan diagram alir perencanaan IPAL sampai dengan operasionalnya.

Beberapa hal yang perlu dipertimbangkan lagi jika pengguna IPAL terdapat lebih dari satu (1) perusahaan atau IPAL yang akan dibangun merupakan IPAL terpadu yang akan dimanfaatkan untuk mengolah limbah yang bersumber dari beberapa industri, yaitu :

- Lokasi IPAL (di kawasan industri / sentra industri kecil).

- Bagaimana hubungan antar perusahaan (harmonis / tidak).

- Bagaimana sistem instalasi saluran limbah antar perusahaan.

- Berapa karakteristik standar limbah yang boleh masuk ke IPAL terpadu.

- Bagaimana sistem kontrolnya.

- Apakah diperlukan unit pre-treatment pada tiap perusahaan.

- Bagaimana sistem pemilahan limbah dan air hujan

- Bagaimana sistem pembiayaannya (investasi, operasional \& perawatannya).

- Siapa penanggung jawab IPAL.

- Bagaimana kesepakatan antara perusahaan dengan pengelola.

Gambar 8. menunjukkan sistem pengelolaan limbah di sentra industri kecil. Limbah dari industri sebelum masuk ke IPAL terpadu harus dilakukan kontrol kualitas terlebih dahulu. Hal ini untuk menjaga agar karakteristik limbah yang masuk tidak mempunyai fluktuasi yang terlalu besar agar tidak mengganggu proses pengolahan. Dengan adanya sistem kontrol limbah ini maka bagi industri yang menghasilkan limbah dengan karakteristik di atas standar yang diberlakukan harus melakukan pretreatment terhadap limbahnya terlebih dahulu sampai diperoleh standar kualitas limbah yang boleh masuk ke IPAL terpadu.

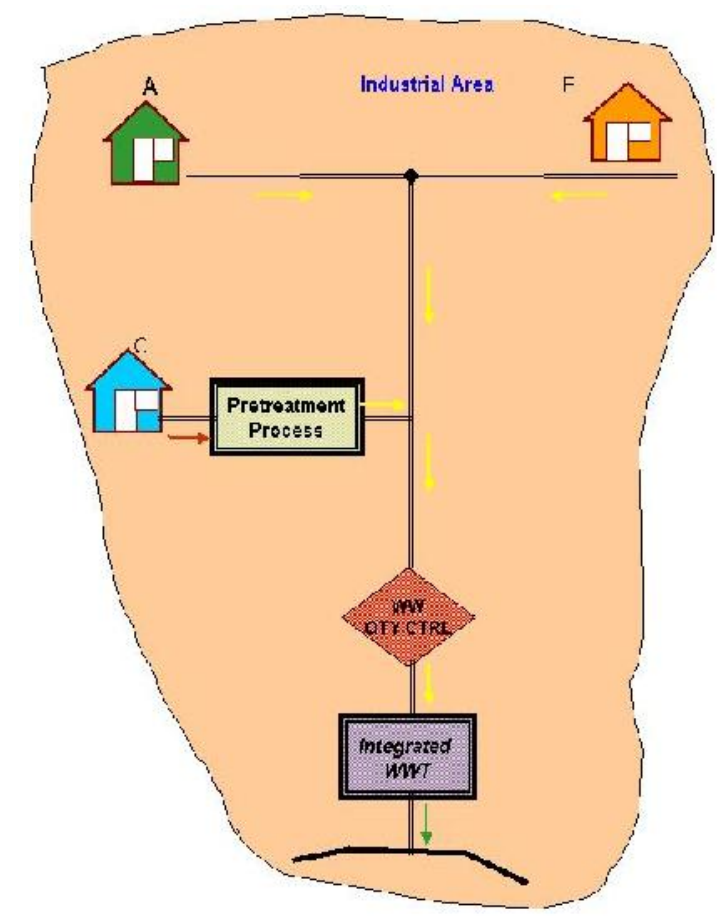

Gambar 8. Sistem Pengelolaan Limbah Sentra Industri Kecil

Sedangkan bagi industri yang menghasilkan limbah dengan karakteristik di bawah atau sama dengan kualitas limbah yang diperbolehkan masuk ke dalam IPAL terpadu dapat langsung menyalurkan limbahnya ke dalam IPAL terpadu. Di outlet limbah setiap industri juga perlu dipasang alat ukur debit limbah, sehingga jumlah limbah yang yang disalurkan ke IPAL terpadu dapat dipantau. Jumlah limbah yang disalurkan ini akan menentukan jumlah biaya yang harus ditanggung oleh industri bersangkutan. Air limpasan saluran (air hujan) harus dipisahkan dari saluran limbah. Hal ini untuk menjaga agar IPAL tidak menerima beban (jumlah) limbah yang terlapau besar di atas kapasitas disain nya. Disamping itu juga untuk menghindari terjadinya pengenceran limbah.

\section{KESIMPULAN}

Dari hasil kegiatan yang pengelolaan limbah industri kecil yang ada di kota Tegal ini dapat ditarik beberapa kesimpulan, antara lain :

- sebagian pengusaha di kota tegal pernah melakukan upaya pengelolaan lingkungan dan pengolahan limbah.

- banyak fasilitas pengolahan limbah yang telah dibangun, tetapi tidak dapat beroperasi dengan baik. 
- tidak dapat beroperasinya IPAL, yang disebabkan oleh beberapa hal di antaranya disain IPAL yang kurang tepat, pemilihan teknologi yang kurang tepat, kurangnya pelatihan operasional IPAL yang ada.

- tidak adanya penegakan hukum berkaitan dengan penegakan peraturan yang ada mengenai pencemaran lingkungan.

- beberapa industri di kota Tegal yang banyak membuang limbahnya secara langsung ke sungai telah disiapkan informasi teknologi pengolahan limbah cair

- telah disiapkan pula perhitungan disain berikut gambar rancangan detail (Design Engineering) untuk unit-unit IPAL sebagai berikut :

- IPAL Perumahan Kapasitas 20 M³/Hari (15-20 KK)

- IPAL Hotel 40 M³/Hari

- IPAL Industri Kerupuk 15 M3/Hari

- IPAL Industri Elektroplating $15 \mathrm{M}^{3} / \mathrm{Hari}$

- IPAL Rumah Sakit Kapistas 5 0 M3/Hari

- IPAL Industri Tahu Tempe Skala Rumah Tangga

- sebagai tindak lanjut pelaksanaan kegiatan pengelolaan limbah industri di Kota Tegal, KAPEDAL perlu melengkapi fasilitas laboratorium lingkungannya khususnya untuk keperluan pengujian kualitas air limbah.

\section{DAFTAR PUSTAKA}

1. ------- (1977). Fate of Pollutants in the Air and Water Environments. Volume 8. Part 2, "Chemical and biological fate of pollutants in the environment". Advances in Environmnetal Science and Technology. John Wiley \& Sons, A Wiley-Interscience Publications, New York, .

2. Adriaens, P., Kohler, HP.E, Kohler-Staub, D., and Focht, D.D. (1989). Bacterial dehalogenation of Chlorobenzoates and coculture biodegradation of 4,4dichlorobiphenyl. Appl. Environ.Microbiol.5:887-892.

3. BPPT, (2002). Laporan akhir kegiatan "Pengkajian Teknologi Pengolahan Air Limbah Industri Kecil Pelapisan Logam". Pusat Pengkajian dan Penerapan Teknologi Lingkungan (P3TL) - BPPT.

4. Chaney, R.L. 1980. Health Risks Assosiated with Toxic Metals in Minicipal Sludge, pp. 59-73. In G. Bitton, B.L Risk of land Application. Proc. Ann Arbor Science Publisher, Inc. Michigan.

5. Forstner, W. 1978. Metal Pollution in the Aquatic Environment. Applied Science Publisher Ltd.

6. Overcash, M.R. (1981). Decomposition of Toxic and Nontoxic Organic Compounds in
Soils. Ann Arbor Science Publishers Inc./The Butterworth Group, Michigan USA.

7. Raka, I G., Zen, M.T., Soemarwoto, O., Djajadiningrat, S.T., and Saidi, Z. (1999). Paradigma Produksi Bersih: mendamaikan pembangunan ekonomi dan pelestarian lingkungan. Penerbit Nuansa, Bandung, Indonesia

8. Setiyono (2002). Sistem Pengelolaan Limbah B-3 di Indonesia. Kelompok Teknologi Air Bersih dan Limbah Cair, Pusat pengkajain dan Penerapan teknologi Lingkungan (P3TL), Deputi Bidang Teknologi Informasi, Energi, Material dan Lingkungan, Badan Pengkajain dan Penerapan Teknologi (BPPT).

9. Sommers, L.E. 1980. Toxic Metals in Agricultural Crops, pp. 105-131. In G. Bitton, B.L. Damron, G. T. Edds and J.M. Davidson; ed. Sludge: Health isk of Land Application. Proc. Ann. Arbor Science Publisher, Inc. Michingan.

10. Stoewsand, G. S. 1986. Trace Metal Problems with Industrial Waste Materials Applied to Vegetable Producing Soils, pp. 423-439. In H.D. Graham, ed. The Safety of Foods, 2nd Edition. AVI Publishing Company; Inc. Wesport, Connecticut.

11. Suffet, I.H. (1977). Fate of Pollutants in the Air and Water Environments. Volume 8, Part 1. "Mechanism of interaction between environments and mathematical modeling and the physical fate of pollutants. Advances in Environmental Science and Technology. John Wiley \& Sons, A Wiley-Interscience Publications, New York, USA. 


\section{LAMPIRAN}

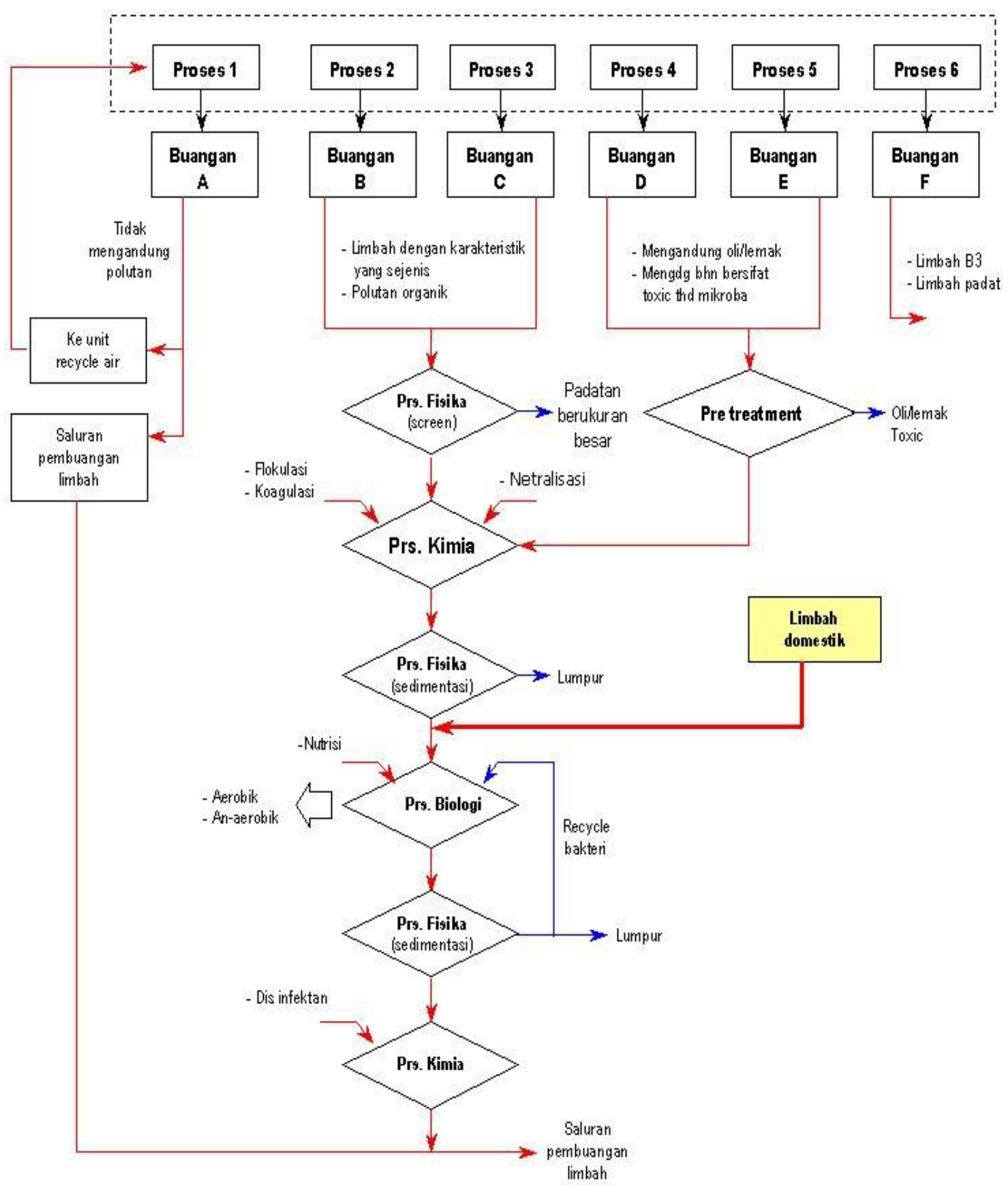

Gambar 5. Diagram Alir Sistem Pengelolaan Limbah Industri 


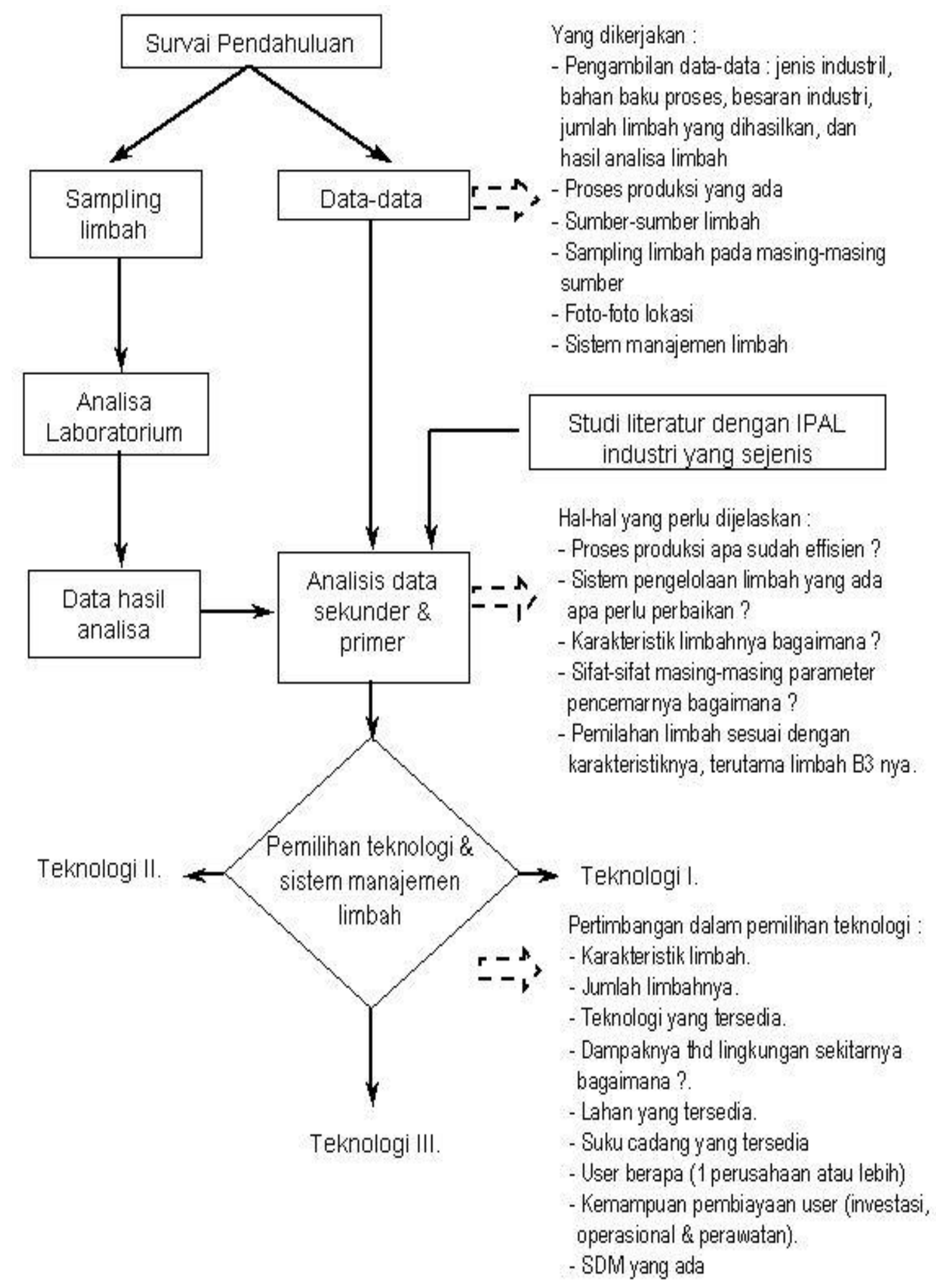

Gambar 6. Tahapan Awal Perencanaan \& Pembangunan IPAL 


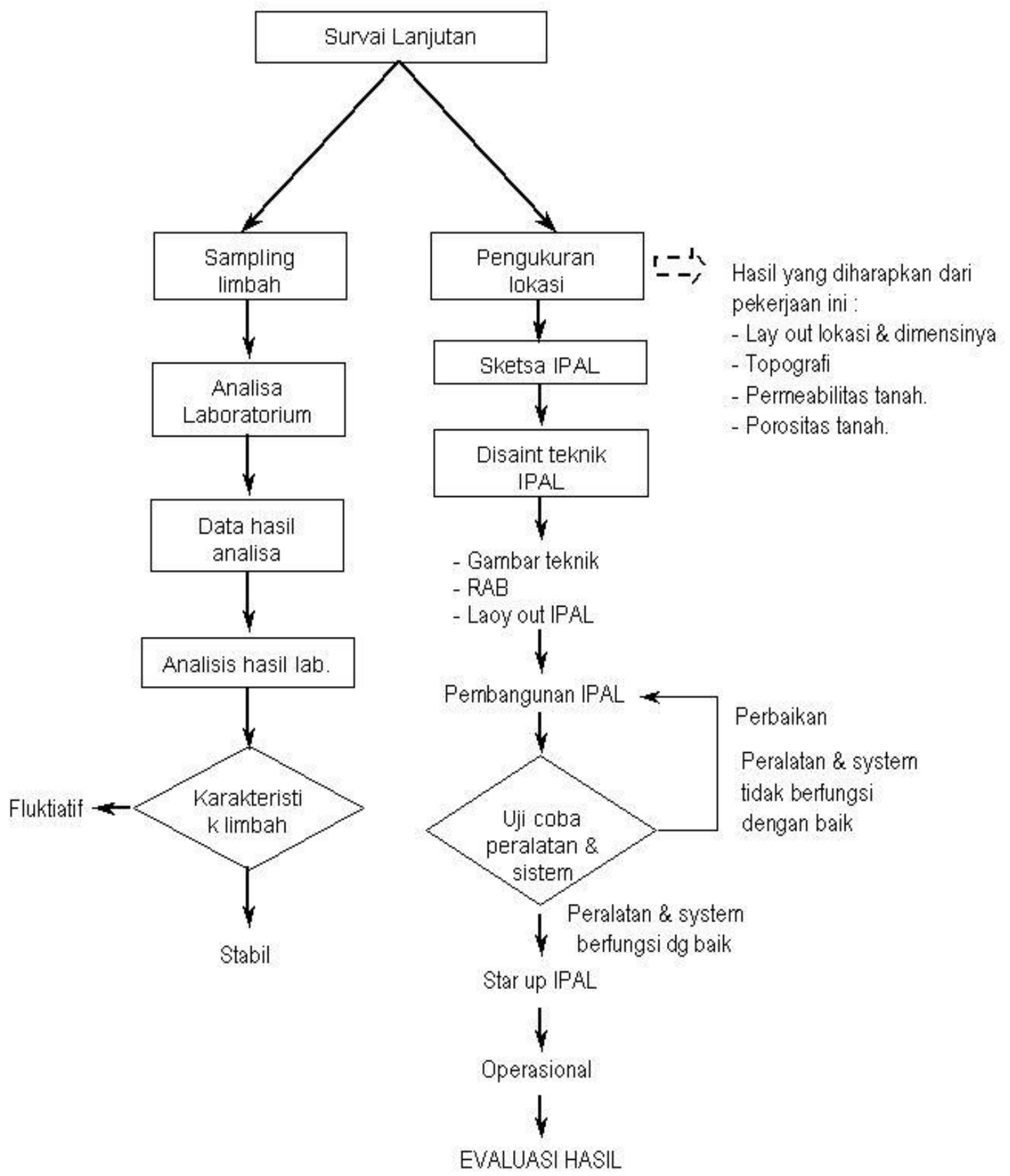

Gambar 7. Tahapan Lanjutan Perencanaan dan Pembangunan IPAL 